\title{
PROGRESS IN ODISHA AND DISPLACEMENT: A VIEWPOINT ON HUMAN RIGHTS
}

\author{
Manoj Kumar Sial ${ }^{1}$ and Dr. Sunil Kumar Padhi ${ }^{2}$ \\ ${ }^{1}$ Research Scholar in Economics, P.G. Department of Social Science, Fakir Mohan University, \\ Balasore-756089, Odisha. \\ ${ }^{2}$ Reader in Economics, P.G. Department of Social Science, Fakir Mohan University, Balasore- 756089, \\ Odisha.
}

DOI: 10.46609/IJSSER.2020.v05i09.010 URL: https://doi.org/10.46609/IJSSER.2020.v05i09.010

\begin{abstract}
S
Growth aims at reducing inequality. Paradoxically, the ongoing development phase in Odisha not only deepened but also expanded the deprivation and triggered displacement on a large scale. In the case of the development model of Odisha, displacement caused by major projects has in reality resulted in the redistribution of wealth from the poorer segment of society to the privileged. Mega dams, thermal power plants, mining, and industrial ventures produce development victims. It can be seen that the larger the project for growth, the greater the centralised control over it. This centralization has a preference for big landholders, prosperous farmers, developers, bureaucrats and politicians. The large-scale development projects are planned primarily to increase the power of state and private capital and they are unable to represent or reflect the needs of the vast majority of the population. With the State's conquest of forests, forest-dwellers' traditional or customary rights were eventually turned into privileges, and even further into concessions. This paper stresses the method of creation in Odisha and its consequences to resolve the problem of human displacement. It also seeks to reassert the protection of the rights of displaced peoples and what needs to be discussed today is the right to growth, through which all of their fundamental rights and freedoms are realised. It concludes that while construction of the infrastructure is important, it must be implemented with a human face in order to mitigate the impact of displacement and achieve the objective of inclusive growth.
\end{abstract}

KeyWords: Development, Displacement, Constitution, Rights and Odisha.

1. Introduction: 


\section{International Journal of Social Science and Economic Research}

ISSN: 2455-8834

Volume:05, Issue:09 "September 2020"

Creation was an important, and even non-negotiable, part of the Indian state's independence modernising agenda. It was clearly defined as encompassing not just an industrial economy, yet at the same time both a social change initiative and a democratic democratisation programme. The history of the last two decades was marked by the development process in general, and the economic transition in India in particular. As in other parts of India, the last two decades have been in Odisha. The design and method of the construction activities has undergone a significant change. In a state like Odisha where an vast majority of the population lives in rural areas and is suffering from chronic poverty, widespread unemployment, subsistence development and weak basic facilities. The preparation and implementation of large-scale infrastructure projects is critical. These projects include dams, electricity, mining, and industrial and infrastructurerelated, transportation, and commercial forestry projects. Nevertheless, there was a shortage of successful infrastructure preparation and implementation Programs. Most of Odisha's development initiatives have had detrimental consequences in the form of displacing people from their traditional homeland and way of life and denying them their fundamental rights to livelihood (Velath 2009). As advanced displaced persons bear the responsibility of growth, at the detriment of its own human rights and social justice. The consequences of externalising the development costs are realised in serious impacts on the environment and in the transformation of people by reducing the enormous variety of ways of life into a significantly reduced collection of social, cultural and economic ties consistent with the industrialised process of production, based on current models of growth.

In pursuit of growth in an age of heightened economic globalisation focused on a neo-liberal development model, Odisha's government policies have favoured increased foreign investment in mining and other related industries. Thanks to its abundance of natural resources and the latest investor friendly Odisha's development policies are increasingly becoming an enticing destination for large companies, both Indian and multinational, looking for opportunities for investment (Sahu 2008). It attracted major construction project in the early 1950s right from the start of the planning period. Among the first major projects undertaken in India were Hirakud Dam and the Rourkela Steel Plant situated in Odisha. The state has seen yet another rapid growth. But the local population, which has a significant tribal component, has not gained from these ventures. The opposite is true: The development paradigm has increased inter- and intracountry socio-economic inequality, displacement and destruction, and has dramatically altered the tribal relationship with their natural environment and resources, which inevitably contributed to the disempowerment of the tribal population (Xaxa, 2001). Finally, the development projects had come to be challenged by proponents of sustainable development policies as well as by campaigns challenging the logic of projects that lead to the growth of certain social classes, even as they cause the displacement of others on a large scale. This paper aims to reaffirm the 


\section{International Journal of Social Science and Economic Research}

ISSN: $2455-8834$

Volume:05, Issue:09 "September 2020"

protection of the rights of Odisha's displaced people and what needs to be discussed today is the "right to growth" through which all of their fundamental rights and freedoms are realised.

\section{Odisha growth and displacement}

Despite its rich natural resources, Odisha could be classified as one of the poorest states in the world, next to Bihar. The state has vast mineral resources with about one-third of the country's iron-ore reserves, massive bauxite, chromate, sulphur, and dolomite (Somayaji 2008). Therefore, State industrialization is a must for eradicating poverty, for opening up job opportunities for education and unskilled labour, in addition to boosting government revenue. Odisha's leaders, primarily politicians, top caste landlords, merchants and the urban middle class have always taken a stand Pro-industry means swift industrialisation. National and regional state political parties have issued false promises to provide employment to rising numbers of unemployed trained youth in the general elections. It can be remembered in the 1980s, when the first child was sold for starvation and Hunger was reported from Kalahandi, then Odisha's chief minister announced 1000 industries to be built in 1000 days. The mega Aluminium plants in the public sector were built in the early 1990s in the districts of Anugul and Koraput. These two sectors displaced more people than they provided for employment (Meher 2008).

Development activities at Odisha began in the late 1940s; the implementation of the Pradeep Port plan brought momentum in the early 50s. The main construction projects that have resulted in large-scale displacement in the state are industrial projects such as the Rourkela Steel Plant, Hindustan Aeronautics Limited (HAL) and the National Aluminium Company (NALCO); multipurpose dam projects such as Hirakud, Rengali; Upper Kolab, Upper Indervati, Balimela, Talcher Thermal Power Station, Ib Thermal Power Plant and Talcher Super Power Plant, and coal mining projects in the Talcher and Ib Valley coal mining areas; etc. The Economy endeavours to promote private investment have been robust at all costs. The State Government has signed 43 memoranda of understanding (MoUs) over the last five years. International and Indian corporate giants are notable among them, namely POSCO (Korea), Vedanta Aluminium (Canada), Rio Tinto (UK). BHP Billition (UK-Australia), Hindalco, Jindal, Tata and Sterlite, Alcan (Canada). Mining projects worth 3,000 billion rupees have been launched already, and projects worth another. The pipeline includes 11.000 billion rupees. Thus Odisha is increasingly emerging as a major site of foreign direct investment and multinational development ventures, undermining the interests of indigenous people in Odisha's hill districts and mineral reserves. (2005 Sahoo). Growth was both a mantra and a myth, as thousands of rupee cores were ploughed into millions of ventures, while the promise of jobs and prosperity remained elusive. For 85 per cent of its population, agriculture is the source of income and employment and never has priority. Because of the disproportionate distribution of wealth it has always suffered from extreme poverty and central neglect in terms of the economic sphere. The poverty ratio for the 


\section{International Journal of Social Science and Economic Research}

ISSN: $2455-8834$

Volume:05, Issue:09 "September 2020"

state was 46 per cent in 2004, the highest in India, according to the report. The cultivable land declined in Odisha. For mines and factories 26, 500 hectares of forest land were lost between 1980-2000. Furthermore, the development juggernaut reduced them to ecological refugees, victims of strategic prosperity, which forced them to pay the development price while others reaped the fruits (Fernandes, 2005).

\section{The Ongoing Misery}

The development-displacement connexion is an ironic one. Due to development ventures, the State of Odisha was experiencing the grim truth of displacement in the process of growth. A startling discovery of the state's displacement is that a large number are among the displaced people are tribal people and other economically vulnerable rural people who relied for their livelihood on natural resources (Fernandes 2009). The sacrifice of millions of displaced tribal people who gave their land, homes, a means of livelihood and suffered in the interests of the nation can only be documented as footnotes in the country's development history. Their pain, misery, all will be forgotten in the project files of the government and they will never find a mention anywhere, as is evident from the storeys of the displaced Hirakud and Rengali. It is not appropriate to go into a thorough review of the different "developmental" projects undertaken after independence and the mania of environment that persists even today, but the fact remains that no one cares about the DPs. It is just their utter determination to create lives in spite of all the adversities and their fighting spirit to keep moving for better forms for recovery which have changed. DPs' struggles both in Rengali, Upper Indravati, Kashipur, and Kalingnagar, or throughout the state, have gone a long way in broadening the development discourse scope, and have also contributed to deepening the country's democratic norms and ethos. Here one could not speak of the Hirakud development project, which affected 285 villages, 22,144 households, 18,432 houses and 112,038,59 acres of cultivated land submerged in the Hirakud reservoir, but all the sacrifices made by the displaced people will still only be counted as a footnote in the history of the "growth" of the country (Baboo 2006).

While a comprehensive directory of the various power and irrigation projects is provided by the State Water Commission, there is no information available on the number of DPs and PAFs. Whatever data there is, just because of the actions of the movements of the citizens, NGOs, academics and researchers. It has been estimated that so far the development projects have displaced 14 lakh people, most of them adivasis, in Odisha sum (Pandey 2008). Due to various projects, the total number of displaced persons in Odisha from 1951 to 1995 is approximately 5, 46 and 794 of whom about 3, 25,000 are responsible for dam projects. In addition, Fernandes, Das, and Rao put that about 8,07,500 people were displaced by 1985-86 because of major projects such as Bhakra, Rihand, Hirakud, Balimela and Upper Kolab. The total number of displaced persons and resettlement in Odisha from 1951 to 2011 is given in the following: 
International Journal of Social Science and Economic Research

ISSN: 2455-8834

Volume:05, Issue:09 "September 2020"

Table.1: Displacement and Rehabilitation Situation in Odisha, 1951-2011

\begin{tabular}{|l|r|r|r|r|r|}
\hline Category & Displaced & Resettled & Percentage & Backlog of settled & Backlog in Percentage \\
\hline Dams & $3,25,000$ & 90,000 & 27.69 & $2,35,000$ & 72 \\
\hline Industries & 71,794 & 27,300 & 38.03 & 44,494 & 62 \\
\hline Mines & $1,00,000$ & 60,000 & 60 & 40,000 & 40 \\
\hline Misc. & 50,000 & 15,540 & 31.08 & 34,601 & 69 \\
\hline Total & $5,46,794$ & $1,92,840$ & 35.27 & $3,53,955$ & 65 \\
\hline
\end{tabular}

\section{Source: India Stat \& Odisha Stata}

The data provided above is only up to 1990, but the situation hasn't changed much, whether in terms of continued displacement due to construction projects, it has actually increased as never before in this hyped up economic boom, or reconstruction period. The per cent of rehabilitated people are the total number of displaced persons, as low as 25-30 per cent. The magnitude of displacement given above by different groups / individuals also shows the seriousness of displacement in India and Odisha, and thus draws particular attention. In the age of liberalisation, privatisation and globalisation, the future is likely to see more displacement cases in Odisha.

\section{Displacement and Rights}

Development-induced displacement ultimately leads to human rights violations. Displacement primarily affects those who are marginalised politically, socially and geographically (Mathur 2006). In recent decades, the drive for globalisation and state development policies has the continuity of their traditional lives has been threatened and they are victims of severe abuses of human rights as a result of the dispossession of their lands and natural resources, systemic brutality and persecution and assimilation. Members are bound by international law Indigenous Peoples and Minorities enjoy all the basic human rights and freedoms of individuals everywhere, and particular international laws have also been established to preserve and protect their rights. The 1986 Declaration on the Right to Growth notes that like the inalienable right of man. The right to participate is based on various provisions of the International Bill of Human Rights, which includes the Universal Declaration of Human Rights (UDHR), the International Covenant on Civil and Political Rights (ICCPR), and the International Covenant on Economic, Social and Cultural Rights (ICESCR). Specifically the 1991 Convention on Indigenous and Tribal Peoples of the International Labour Organization Independent Countries (ILO Convention 169) stipulates (Article 7) the involvement of indigenous and tribal peoples in the creation, implementation and evaluation of the national and regional development plans that concern them (Velath 2009). 


\section{International Journal of Social Science and Economic Research}

ISSN: 2455-8834

Volume:05, Issue:09 "September 2020"

The development-induced displacement process in Odisha takes away many rights from the displaced, which the Indian Constitution in turn grants them. Ironically, Article 19(e) of the Indian Constitution grants its citizens the right to "reside and settle in any part of India's territory" and Article 21 states that "no one shall be deprived of his life or personal liberty except as provided for by law." Thus, when the state removes land, CPR-dependent communities are deprived of their livelihood on the premise that the natural resources are state property "the right of the state to itself is contrary to the fundamental rights of the citizen" (Fernandes and Paranjype 1997). According to Article 19 of the Indian Constitution, every citizen has the right to freedom of assembly, freedom of speech and expression. But government and private businesses in Odisha have been repeatedly threatened by the use of police and paramilitary powers, which is a breach of the right to peaceful assembly (Meher 2006). Odisha has undergone many struggles over the last two decades to preserve life and livelihood (e.g. in the towns of Balipal, Gandhamardan, Chilika, Indravati, Gopalpur, Kashipur and Kalinganagar). The Police fire in Gopalpur, Maikanch and Kalingnagar, which resulted in the loss of poor and tribal lives in opposition to mega-development projects, can be seen as denying their core livelihood rights and the continuing dispute between the two sides: between the government-led 'industrialization' preference and those opposed to it. If the politically elected continues to abuse tribal rights, which is very democratic from the subaltern viewpoint, then the weaker segment of society will become more dehumanised and excluded, resulting in resistance movements like violent protests (Samal and Das 2006).

\section{Place alienation and local people's rights}

Land is a particularly contentious issue in terms of development projects, especially in areas with tribal communities, and understanding the constitutional provisions here is crucial. The deprivation of tribal land, water, and forests occurred through a process of incremental, systemic, and questionable acquisition of these rights under the intrusion of the British colonial state into the sphere of customary common property. The tribal and rural people are displaced from their economic assets and homes because of large-scale industrial and infra-structural projects. State Acquisition 1894 Act (amended in 1984) empowers the government to seize land from the citizens by coercion for public and private purposes, also called "national interest." This Act assists the State as a tool for the immediate acquisition of property. It is in line with this theory of the Indian state's "eminent domain" that the state's possession or property rights came to violate the rights of the displaced peoples (Ramanathan 1996).

Odisha seems to have been the latest indication of the immaturity and ineptitude that distinguishes much of India's political institutions in the eastern Indian state. Some of the major acquisitions in the years following independence such as those for the Hirakud, Machkund, Sileru and Rourkela dams Odisha steel factory. In the 1950s, 1, 12,038.59 acres of cultivated 


\section{International Journal of Social Science and Economic Research}

ISSN: $2455-8834$

Volume:05, Issue:09 "September 2020"

land were acquired for the Hirakud dam in Odisha and today, 50 years later, according to the Odisha government, approximately Rs 6 core (out of the total compensation of about the Rs 9 core) did not meet the 3,098 affected. Odisha Land Reforms Act 1960, section 22 prescribes prohibitions on land alienation by members of the Scheduled Tribes to non-scheduled members of the tribal group. This becomes more significant in the sense of the tribal upland rights that these lands have enjoyed as their ancestral territory from time immemorial, but the government's imperial authority alienates people from their conventional sources of livelihood and social networks, causing untold suffering and misery (Sharma 2003).

Since 2006, the recent protest movements against land acquisition in Kalingnagar for Special Economic Zones (SEZs) have stirred a national debate on the rights of displaced persons and given attention to the fact that construction-induced displacements are stakeholders in the construction and they should have the right to equal marital rights (Pandey 2008). In May 2006, the government of Odisha announced a new draught policy on resettlement and rehabilitation (ORRP), which provides for interalia, "estate for property" compensation for the acquisition of land for development purposes and SEZs and jobs for at least one person from each family concerned. But in Odisha, the resettlement programme did not accept this failure, nor adequately compensate and thus deprived them of their right to livelihood. In addition to the R\&R policy a patrilineal definition of property rights was supported by Providing land entitlements only for children over 18 years of age and unmarried daughters and sisters over 30 years of age. That raises important social justice and equity issues. India's constitution does not specifically recognise the right to be protected from losing one's habitat and means of subsistence. Article 21, which confers the right to life, is without doubt one of the most commonly read in Constitutional clauses. It is up to the states to decide to what degree populations that are dislocated and suffer habitat loss and livelihood loss will have a say in the matter of being compensated for losses in livinglihood.

\section{Constitutional laws and the freedom of the citizens}

Public structures are rooted socially and work within the framework of social and economic disparity. The local institution can be advantageous in the process, functioning as an important factor in implementing R\&R policy. Under the Odisha adaptation of the Central Panchayat Extension to the Scheduled Areas Act, 1996 (PESA), it is legally established, for the first time in Odisha, that the Grama Sabha or Srama Sasan will exercise ownership rights over the minor forest production. The act gives the Grama Sabha and Panchyats comprehensive control in Fifth Scheduled Areas. It requires consultation with the Grama Sabha and/or Panchyats to be mandatory in both land acquisition cases for development projects and before planning a resettlement and rehabilitation plan for the affected tribal community (Bandopadhya 2004). The PESA seeks to provide comprehensive tribal protection against arbitrary, discretionary and 


\section{International Journal of Social Science and Economic Research}

ISSN: $2455-8834$

Volume:05, Issue:09 "September 2020"

scheduled areas motivated State action relating to the acquisition of land. The state has never, however, consulted on the form of development people want, thereby violating the right to decide their own goals as part of the right to development as an inalienable human rights (Bharati 1999).

The Odisha Government is signing Memorandum of Understanding (MoU) with an en-number of firms setting up mega projects. The mining lease granted to UAIL, Vedanta Alumina Limited in the Kalahandi district block of Lanjigarh is unlawful, indeed unconstitutional. The region in which the lease was granted is the Scheduled Region, that is, the territory governed by the fifth Schedule to the Indian constitution. In these areas, the governor is empowered to make the regulation, repeal or amend any law of parliament to prohibit or restrict the transfer of land by or among members of the scheduled tribes or regulate the allotment of land to members of the Scheduled tribes in such area (Sahu 2008). The Supreme Court in Samatha vs. Andhra Pradesh State (AP), 1997, categorically held that the transfer of land to a non-tribal by any means including the Government's lease under Schedule Fifth is unconstitutional. It was held that the executive should be equally aware of the constitutional duty to protect and empower tribal's, while exercising the constitutional right to dispose of its land. The court is therefore necessary to give effect to the constitutional mandate and legislative policy of a complete prohibition on the transfer to nontribal of the land in the Scheduled region.

\section{Regulation of law}

The rule of law remains eminently observable in terms of the openness of governance and public accountability of the class of development lists, if not necessarily the philosophy of growth which can, and indeed does, run counter to the concept of the rule of law (Baxi 2009). In the application of Law, a conspicuous double set of principles is clear. According to Article 19 of the Indian Constitution, every citizen has the right to freedom of assembly, freedom of speech and expression. The not-so-hidden growth costs in the developmental governance framework of Odisha state intensify government commitment and devotion of excessive resources in police, paramilitary, and related security forces. Police and paramilitary forces have repeatedly disrupted peaceful democratic assembly alongside goond as hired by corporations is a violation of the right to peaceful assembly. The security forces of the Odisha government were responsible for a reign of terror against the adivasi through arbitrary detention, torture, custodial death, maiming, rape and extrajudicial killings. The armed police are marching past villages and conducting routine patrols as a way to instil fear in villagers and extort their consent. Instead, Odisha's government decided to rely on police rather than democratic dialogue: they initiated a systematic effort to censor and eliminate opposition to the project through disproportionate use of force (Padel and Das 2009). 


\section{International Journal of Social Science and Economic Research}

ISSN: $2455-8834$

Volume:05, Issue:09 "September 2020"

Police forces detain community leaders, activists and those classified as opposed to the project including women and children, w protesters against the UAIL, POSCO, and Tata projects are arrested in numerous false cases. Most arrests seem to be focused on trumped-up allegations of dacoit or arson, and strict law interpretations. The arrest on 2 December 2004 of Bulka Miniaka, a respected member of the Kashipur group, on charges of a dacoit, the assassination of antiPOSCO activist Dula Mandal by pro-POSCO goons on 21 June 2008, then the shooting down of social activist Amin Banara near the Tata factory site on 1 May 2008 and the assassination of several leading activists by hired goons or the repression of the State by company The complicity between the Odisha government and private corporations in suppressing people's interests and aspirations explains the atmosphere of impunity surrounding the incidences of abuse. The Odisha Government should uphold the rule of law, in particular to enforce the Samatha judgement; Cancel any unconstitutional leases on mining and refrain from potential constitutional leases on Adivasi land. (The Products 2007).

\section{Forest Rights in Odisha}

Since 2008 the Forest Rights Act (FRA), passed by Parliament in 2006, has been introduced in India. It provides a constitutional framework for the redress of the country's ancient forest injustice dwellers, like Odisha. The Act was a result of concerns about growing land theft, and in the last two decades the resettlement of forest dwellers was imminent. The Act was about preserving the tribal and forest dwellers' rights about their ecosystems. The Act also offers protections against the unlawful displacement or resettlement of tribal and other living / dependent forest dwellers from protected areas. The FRA was not introduced in Odisha a however comprehensive and focused more on giving individual claimants land rights than community claimants (Sarap et al 2013).

According to the 2011 Census, scheduled tribes (STs) constitute 22.8 per cent of the total Odisha population. 62 tribes, including 13 especially vulnerable tribal groups (PTGs) are affected. Odisha had an exceptionally long tradition of traditional forest privileges. Recognizing the symbiotic relationship between tribal's and forests, setting up industrial projects, laying down railroad tracks, Building towns and collecting raw materials for factories has given rise to a phase of deforestation and creates precarious living conditions for tribal and indigenous communities in Odisha's hilly areas and tribal belts. The agreement between the Odisha government and Vedanta Alumina to allow the mining of bauxite deposits in the Niyamgiri hills, the home of the Dongaria Kondha tribe, is an example of how state-supported corporate interests trample on tribal livelihoods and threaten an ecologically rich and valuable area (Sahu, 2008). However, if the Odisha's recent stand is Government against UAIL and SIIL is any indication, then the agreement violated the forest rights act as the state government did not take into account the local communities, especially the tribal ones. It signified the tribal community's earlier loss 


\section{International Journal of Social Science and Economic Research}

ISSN: $2455-8834$

Volume:05, Issue:09 "September 2020"

of rights over the forest and land linked sources (Mohanty 1998). In the meantime, in the mad rush for exploitative development, the rights of the working class and the marginalised are violated. It thus becomes the duty of all the people concerned to enter efforts to create collective and long-standing resistance against ideas and acts that deprive people of their right to life and livelihoods.

\section{Rights to intellectual property}

Odisha's main tribal communities are the Khond, the Saora, and the Bhuiya, with strong indigenous knowledge aside from the Gond, the Munda, the Dongaria and the Santal. The new paradigm of growth has given away the vast conventional ethno-biotic expertise and ability base that the Odisha Mainstream Tribal Groups (Mahapatra, 1994). The tribal's declaration of intellectual property rights is an apt way to thrive in the global economy. Intellectual Property Rights (IPR) includes the protection of indigenous knowledge bases in fields such as medicinal plants, biodiversity of agriculture and environmental conservation and reimbursement for the use of their skills by indigenous peoples. Besides plants indigenous people have attracted attention to new crop varieties, organic pesticides, sweeteners, exotic vegetables, preservatives and perfumes. In the age of liberalisation, skilled gene hunter's researchers visiting subcontracted by foreign corporations speak to the tribal's and take their samples. When the samples are processed and a product is made, the so-called invention is patented, and the rights are owned by the project-backed company. Section 5.2.2 of the National Environment Policy 2004 provides for legal recognition of tribal intellectual property rights, but the tribal traditional information base is either ignored or not legally acknowledged by international sources.

\section{Environmental Cost and Living Assistance}

Environmental security is specifically given in India's constitution and that mandate has been enhanced by judicial interpretation. Despite India's pledge to the Climate Convention, green house gas emissions have skyrocketed in Odisha. The climate and the social structure of Odisha are seriously threatened by large-scale mining and industrial activities, with more severity anticipated in the coming year (Goodland 2007). The state actually releases large percent of the greenhouse gases in the world. At the current pace of growth, this figure is projected to increase to one per cent by 2020. The Environmental clearances issued to the UAIL, POSCO and Sterlite industries, without the use of rapid environmental impact assessments, establish a conflict of interest and breach the legal standards of National Environment Policy 2006. It has been shown in the past that the NALCO smelter in Angul has been built in a position where the level of fluoride in the groundwater was already high due to inappropriate environmental impact assessment study and identifies eleven villages that have been affected by the rise in fluoride levels, which can pose serious health risks. In addition to triggering dramatic climate changes 


\section{International Journal of Social Science and Economic Research}

ISSN: 2455-8834

Volume:05, Issue:09 "September 2020"

and a reduction in wildlife ecosystems, mining in Odisha has threatened thousands of Adivasis' livelihoods. It takes away the advantages of state mineral wealth from future generations. Marginalized people are forced to live with water scarcity as rivers are diverted for industrial use, ash dumps, red mud stacking and chemical effluents disposed of in rivers not only contaminate water, rendering it unfit for human and animal use, but also damage their agricultural lands and kill their goods (Samal and Das 2006). The main impacts of construction activities are habitat destruction and survival, environmental risks, the inadequacy of compensation arrangements, the shortcomings of the proposed rehabilitation scheme and the socio-cultural impacts on the citizens. When people directly affected by emissions or construction proposals are forced to take part in the decision, along with business representatives and government officials, the company and developers cannot manipulate the local environment or neglect the community. Design in such a setting is more likely to be environmentally conscious and to be tailored to justice.

\section{Conclusion}

The human rights component of the development process has often been overlooked, as it does not fit well into the prevalent development conceptions. The plight of indigenous people in Odisha has reported in recent years that it has become a particular topic of concern in the international human rights agenda, as well as in domestic legislation and policies. Displacement isn't about to wane. Development strategy predictably presumes that displacement is unavoidable. There is an attempt to justify it, as "national interest" in turn diminishes the ability of poor people to access and use natural resources profitably. The Odisha government's technocratic development model was thoughtlessly derivative and has proved economically iniquitous, environmentally unstable and politically less than democratic in its denial of the right to education and employment. Development is required, and indeed essential, to improve the living conditions of marginalised communities in Odisha. It cannot, however, take place without the involvement of those who could stand to lose a substantial portion of everything that is of importance to them. What is needed, therefore, is an alternative development model, a model which believes the "small are beautiful" and effectively counteracts the large which symbolises unsustainable and elitist growth. It must be man-oriented, and based on nature. The fruits of growth should not only go to the fortunate beneficiaries; every opportunity to be a part of the benefits of the project should be granted to all the affected people. Relocation and recovery initiatives should be participatory, so that all interested parties are active in the relocation phase. Compensatory programmes should not be half-hearted, and should provide the displaced with an adequate environment, job opportunities, educational facilities, food security and health care facilities. The whole problem of displacement must be seen as a complex question of human rights, political, social, economic and cultural and not just an administrative one. Displacement 


\section{International Journal of Social Science and Economic Research}

ISSN: $2455-8834$

Volume:05, Issue:09 "September 2020"

policy, practise and research should not only concentrate on the risks and effect of displacement, but should also concentrate on institutional development processes that will protect and improve the rights of displaced women and men, including their right to knowledge, shelter and development. The challenges the mechanism faces require strong resolve, continuous government political engagement, money, capability and over a period of time. Therefore it is the state's duty to ensure that the processes of reform and development aim are driven in such a way as to achieve the constitutional objective of establishing a vibrant democratic welfare society.

\section{References}

- Baboo, Balgavind. (2001).Dams, Displacement and Violation of Human Rights: Case of Hirakud Dam in Odisha in Katare, P. M and B.C. Barik (ed.) Development, Deprivation and Human Rights Violation, New Delhi: Rawat Publication, 195-208.

- Baxi, Upendra. (2008).Development, Displacement, and Resettlement: A Human Rights Perspective, Indian Social Development Report 2008, Council for Social Development, New Delhi: Oxford University Press.

- Fernandes, Walter \& Asif, Mohammed. (1997).Development-induced Displacement in Odisha 1951 to 1995: A Database on its Extent and Nature, New Delhi: Indian Social Institute.

- Velath, Priyanca Matur. (2009).Development and Displacement: Rights-based Theoretical Analysis, in Renu Modi (ed.), Beyond Relocation: The Imperative of Sustainable Resettlement, New Delhi: Sage Publication.

- Somayaji, Sakarama. (2008).Man-made disasters: Displacement, resettlement and rehabilitation in Odisha-Reflection from the field, Social Change, Vol.38, No.4, December: 689-704.

- Sarap, Kailas, Tapas K, Sarangi \& Jogindra, Naik. (2013). Implementation of Forest Rights Act 2006 in Odisha: Process, Constrains and Outcome, Economic and Political Weekly, VolXLVIII, No.36, September : 61-67.

- Sahoo, Sarbeswar. (2005).Tribal Displacement and Human Rights Violation in Odisha, Social Action, Vol. 55, April-June: 153-66.

- Sahu, Geetanjoy. (2008).Mining in the Niyamgiri Hills and Tribal Rights, Economic and Political Weekly, April: 19-21.

- Padel, Felix \& Samarendra Das. (2008).Cultural Genocide: The Real Impact of Development-induced Displacement, Indian Social Development Report 2008, Council for Social Development, New Delhi: Oxford University Press. 
International Journal of Social Science and Economic Research

ISSN: 2455-8834

Volume:05, Issue:09 "September 2020"

- Meher, Rajkishore. (2006).Globalization, Industrialization and the State: A Sociological Study of Tribals Reaction to Industrial Development in Odisha, Paper presented at the Seminar on Towards a Sociology of South Asia, January 27-28, New Delhi.

- Mahapatra, L.K. (1994).Tribal Development in India, Myth and Reality, Delhi: Vikas Publication House. 